\title{
Understandıng marketing and marketing policies in international markets
}

\author{
Hazel T. Suchard \\ Department of Business Economics, University of the Witwatersrand, Johannesburg
}

Marketing and marketing policy in international markets, must be based, according to the authoress, upon the level of economic development within a specific country and regions within a specific country. The authoress proceeds to provide stages in development and discusses the implications for product policy, pricing policy, promotion policy, and distribution policy. The impact of other economic factors, cultural forces, political and legal forces are also discussed. The authoress concludes by referring to rural versus urban distribution and its influence on international marketing.

S. Afr. J. Bus. Mgmt. 1985, 16: $49-53$

Bemarking en bemarkingsbeleid ten opsigte van intemasionale markte, moet volgens die skryfster gebaseer word op die vlak van ekonomiese ontwikkeling van ' $n$ spesifieke land en selfs areas binne daardie land. Die skryfster stel dan ook 'n aantal stadia van ontwikkeling voor en bespreek die implikasies daarvan vir produkbeleid, prysbeleid, promosiebeleid en verspreidingsbeleid. Die invloed van ander ekonomiese faktore, kulturele magte, politiese- en regsverwante magte word ook bespreek. Die skryfster sluit af met 'n verwysing na stedelike versus landelike verspreiding en die invloed daarvan op internasionale bemarking.

S.Afr. Tydskr. Bedryfsl. 1985, 16: 49-53

H.T. Suchard

Department of Business Economics,

University of the Witwatersrand, P.O. Box 31170 ,

Braamfontein, 2017 Republic of South Africa

Accepted June 1984
Attractive opportunities in foreign countries have led many companies into international marketing. Marketers are realizing that selling products in certain parts of the world is quite different to selling products in other parts of the world. To ascertain the differences between different markets, market segments have to be defined as precisely as possible and a systematic study must be made of target markets. Marketers must understand environmental aspects of international marketing before a marketing mix can be formulated. Selected aspects to be considered here are economic forces such as stages of economic development, cultural, political, and legal forces, and a demographic factor of urban versus rural distribution. For each of these aspects, marketing practices will be discussed in terms of the functional areas: Product policy, pricing policy, promotional policy, and distributional policy.

\section{Stages of economic development}

Different stages of economic development may be identified. It must be realized however, that not only different countries, but different parts of the same country, may be at different stages of economic development, and that in some countries stages have been skipped, for example because of the entry of multinational companies and subsequent infusion of capital. Six stages of economic development have been identified by Jerome McCarthy $(1981: 648-650)$. The first stage is that of subsistence farming found, for example, in some parts of Africa and New Guinea. The second stage is the pre-industrial or commercial stage. Raw materials, agricultural, and forest crops are grown and exported. While the majority of the population still provide for their needs via subsistence, there are both technical and supervisory people, a few large landowners and a small, middle-income class made up of employees of the larger firms. Examples of countries in this stage are some countries in Sub-Sahara Africa and the Middle East. In the third stage, metal ores or agricultural products are produced and processed. Although a large part of the population is still at subsistence level, the local market expounds and there are still foreign technicians and supervisors and a growing number of wealthy inhabitants. Indonesia and the oil producers of the Persian Gulf are examples. During Stage 4 there is small local non-durable and semi-durable consumer goods manufacturing. The ranks of the middle and upper-income class are expanded by some of the small manufacturers. Countries in Stages $1-4$ may also have few commercial agents, limited trade or business apparatus, and foreign companies may operate in monopolistic conditions. These countries suffer from a lack 
of transpon facilives with underdereloped ports and no direc shipping lines. coonomic instability ow ing to potitical

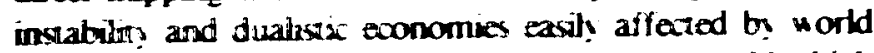
crises. Those with infana industres may be protaced by high tanffs and adminisurane rescricions. There ma also be trade discrmination ox ing to afritiation of these cournines with imernational trade bodies such as the common market and frex-trade areas and gonemment ounership of the various means of production and markeing utich imerferes with free emespnxe. During Staqe S industralization begins with the production of capial goods and consumer durable goods. Stage 6 imsolves exporing manufactured products. most consumers no longer barter and are pan of the money econom! There may be a targe middle-income class. Evamples of countries in the sivth stape are the Linied States. most uestern European countries. and Japan.

What do these sapes of development imply for the marketers product proce, promorion. and discribution policy?

The population of Stage 1 are not a marker as are most of the population in Stage 2. In Stape 2. however, there is a market for indussial machinery. equipment, and luxury goods to satisfy the demands of technical and supervison: peopte. The marke is large in Stage 3, but still limited. The countries in these sages of development also have lower personal and per capita incomes. lowet rates of grouth of busing pouer, and to a lesser extent, of available consumer financing. In these countries necessities are important and the product should have neod-satisfying qualities. In Stage 4 there is a market for consumet durables and capital goods which moets with no competition from local products. This latter compecition arises in Srage 5, however the foreign community and status-oonscious wealhy, having a preference for imports, consiture the major pan of the market. There is also a market for heary machinery and equipment in Stage 5. In Stage 6 there are markets for a greal variety of products. As countries of this stage are exporting countries thes are obliged to import products of countries to which they expon. An example of this is the case of Japan. A variety of foreign products are found in Japan's department stores and shops, for example: Furs from the LSSR, shoes from Italy, silk from China, beef from Australia, etc. Foreign products thus compere uith one another in antempting to capture Japan's markets.

As far as pricing policies are concerned, in the early development slages, as purchasing power is low; prices should be as low as possible. Pricing is also important for countries in the final stages, when competitors prices have to be taken into consideration. These countries constitute the largest and most profitable markets as there are more customers with higher incomes.

Promotion is concerned with communicating information and persuasive appeals effectively. Promotion is limited by illiteracy and low living ssandards, and advertising is irreterant for populations in the early stages of development. Personal selling and word-of-mouth advertising tends to be the most successful and effective promotional technique and this should be coupled with demonstrating the use of the product. This often takes place in traditional bazaars and markets. As countries become more developed, radio and TV become important media to reach consumers. These media are also able to overcome the illiteracy problem in developing countries. Wall posters and pictorial representation of products on walls or roadsides can also be used. In countries such as India and Africa drum beatings can be used to spread awareness about a product among potential consumers. As literacy increases together with development, newspapers, magazines, motion-picture adierising. and direca mail can be used. Adterising apencies abso come into ther oun. Individual national adierising campaigns an be produced for economically detetoped markets hecause of the high profit porential, but tailoring communiation media to each underderetoped marker would be too costly for a company which is Ining to gain a foothold in the market. In mose deseloping countries demand exceeds supply for mox consumer goods and the major task of adierising is to create a demand for a product class. This is not the case in detetoped countries such as America and Canada where. as a result of compecition. advertising is used to create setecive demand for product brands.

Urtanization is a feature of tie more det etoped countries, whereas sillages tend to be a icature of the less deretoped countries. Thus, in the less decetoped countries. marketers have to gear their marketing srategy to a nural market as discinct from an urban marker. The panizular strategy will be discussed in this article under the heading "rural versus urban distribution. In the early sages of devetopment a minimum number of channels of distribution should prevail between manufacturet and consumet as the number of middlemen determine the price of a product. For countries in adranced stages of development. the most conmon ctannet for manufactured products is that of manufacturet - whotesaler - retailer and consumer. The problem of underdenetoped ports and no direct shipping lines that may be characteristic of a small developing country can be solved by transhipment through a country having close economi and trade relations with the small developing market.

Table 1 shous the implicarions of the sages of development for the marketers product, price, promotion, and distribution policy.

Considering the stages of economic development can be used as a firs step in segmenting international markets. There are, howeret, other economic factors that are also impontant.

\section{Other economic factors}

Insights into market potential can be gained from knowledge about countries gross national products. income per capita, income distribution, disposible income, and availability of consumer credit. Greater marker porential is usually indicated by higher income. The gross national product is an overall measure of a country's economic standing and is the total market value of goods and services produced in a vear. There are problems that arise with the use of gross national product (GNP). The measure does not include activities of selfsufficient family units, and does not therefore give a true picture of economic standing in less deretoped countries. GNP per capita should also be taken into consideration because, while the GNP of a small country may be low, the GNP per capita may be high. GNP per capita is a measure of the standard of living, but even here there are problems and entrepreneurs may derive incorrect views of market potential. GNP per capita cannot be used for comparison as income is seldom eveniy distributed amongs all consumers, as in the example of South Africa where there is distribution on racial lines. The study of income distribution is imponant for the marketer. The extent of available consumer financing is also important as the greater the extent, the higher the market potential.

As far as product planning is concernend, while it is true that entrepreneurs should sell where the income is, there are opportunities for marketers in countries with lower incomes. Ferrell \& Pride (1982:458) give the example of Litton's 
Table 1 Stages of development and the marketers product, price, promotion, and distribution policy

\begin{tabular}{|c|c|c|c|c|}
\hline $\begin{array}{l}\text { Stages of economic } \\
\text { development }\end{array}$ & Product policy & Pricing policy & Promotion policy & Distribution policy \\
\hline \multicolumn{5}{|l|}{ Stage 1} \\
\hline \multicolumn{5}{|l|}{ Stage 2} \\
\hline Pre-industrial & $\begin{array}{l}\text { Small, limited market } \\
\text { for industrial machinery } \\
\text { equipment and luxury } \\
\text { goods }\end{array}$ & $\begin{array}{l}\text { Prices should be as } \\
\text { low as possible }\end{array}$ & $\begin{array}{l}\text { Advertising irrelevant. } \\
\text { Personal selling, product } \\
\text { demonstration. }\end{array}$ & Manufacturer consumer \\
\hline
\end{tabular}

Stage 3

Expansion of local market
Large, limited market. Necessities important
Prices should be as low as possible
Newpapers, motion picture advertising, direct mail.

\section{Low prices} durables and capital goods

Stage 4

Small local non-durable and semi-durable consumer goods manufacturing

Stage 5

Industrialization begins Foreign community and wealthy $=$ market for heavy machinery and equipment.

Stage 6

Exporting of manufactured products

\author{
Markets for great \\ variety of products
}

As above and national advertising campaign.

\author{
Low prices, \\ competitors prices \\ must be considered
}

As above and advertising agencies

Manufacturer - retailer consumer

\author{
Manufacturer - retailer - \\ consumer
}

Manufacturer - wholesaler retailer - consumer microwave ovens selling in Mexico and Brazil, which illustrates this point. Higher income groups do, however, tend to purchase different consumer goods to lower income groups. For example, higher income groups purchase products linked with affluence and leisure time. Thus it is that the study of income distribution within foreign countries becomes important. Products for countries with higher GDP's and those with higher GDP per capita should be higher priced as individuals should be more able to afford them. As more highly developed countries tend to have higher GDP's and GDP's per capita, the points made above concerning distribution and promotion also apply here.

\section{Cultural forces}

The cultural environment of different countries and hence different markets differs and influences the buying motives and habits of consumers in different markets. There may be cultural differences in language, colour, design preferences and attitude to time and space. Different cultural groups also have different behavioural characteristics.

Taking Japan as our example, the Japanese have a very complicated writing system and the Japanese language is very different from most other languages. In Japanese, General Motors 'Body by Fisher' translates as 'Corpse by Fisher'. Black and white are the colours of mourning, the metric system is used for measurement and while the Japanese expect promptness at a social event, they do not expect promptness for a business meeting. The Japanese are interested in new things and have a liking for change. They live in small living units and while in the past their staple diet has consisted of fish and rice it is changing to red meat and bread. Although they have their own culture, they are knowledgeable and interested in the rest of the world, particularly the United States and Europe. They have a high standard of education and are avid readers. Human relations of long standing are considered important as is regard for human relations. The Japanese do not like losing face, value product safety and cleanliness. They attach importance to seniority, have little class consciousness, the majority being of the middle class. Whereas a 'follow-the-pack' syndrome used to exist, the environment is changing and the Japanese are expressing personalized tastes. There is also a revolt against old traditions, for example, young people no longer consider that they have to eat at home. They have a very high ratio of savings to disposable income and are interested in upgrading their homes.

Product, price, promotion, and distribution policy must be adapted to the relevant cultural forces. When marketing in, for example, Japan, product slogans must be translated carefully before they are used. Japanese language catalogues and specifications are required. As black and white are the colours of mourning they should not be used on products. The product should be adapted for Japanese tastes. CocoCola, for example, changed its taste and product ingredients to suit the Japanese market. While American and European products are acceptable, because of the Japanese liking for change, a market policy may have to forecast a life cycle of a product. Size, content, and mass are important because the Japanese live in small living units. The fact that the youth market is more western-leaning is significant for the apparel, electrical appliance, and fast-food industries. This trend is illustrated by the success of McDonald's in the Japanese market. 
The attraction of certain products in the Japanese markets may lie in their price. However, productivity in Japan is high and material costs are cheap because of volume purchase and good utilization. Because the Japanese market is well supplied with a great variety of goods, only correctly priced products of good quality have any chance of finding buyers. Because of fierce competition, products may have to be offered at prices lower than those charged for competitive products. Although this means that profit margins are small, the exporter, by producing a large quantity for both the home and an export market, accomplishes a reduction in unit costs as fixed overhead costs remain the same and his total profits are higher.

There are a number of factors of importance to promotion. Promotion should not be based only on rationalism. In Japan, regard for human relations is necessary in promotion directed at wholesalers and retailers. Yoshiro Hasegawa (1978:62-64) gives two examples which illustrate this point. The president of a foreign firm in Japan visited a wholesaler with whom he had business relations to offer his condolences immediately after he heard of the death of a member of the wholesaler's family. Whenever the board chairman of a large appliance company goes away on holiday he always visits local retailers to pay his respects. Another factor of importance is advertising, which is extremely important for promotion. To be effective advertising must be sufficiently powerful and should be decided by taking into consideration the size of the sales-promotion budget. It may be that sufficiently powerful advertising or promotion cannot be financed by a single firm. In that case a joint campaign could be organized and financed by a trade association. General trading companies in Japan provide a complete marketing and goods-handling service for many products which are imported into Japan. Products which require extensive marketing and promotion are handled by specialized trading firms rather than general trading firms. Exporters have to decide which trading companies to use. Their decisions may be influenced by the extent to which the trading company controls processing, distribution and the network for final sales, the trading companies ability to provide financing, and the company's product experience and group affiliation.

Japanse distribution/sales systems are complex systems that have developed over decades and have become firmly entrenched. There may be at least five stages: Importer, wholesaler, first distributor, second distributor and retailer. While these may be an attempt to bypass wholesalers, for some products direct selling to retailers is not possible. Furthermore, the Japanese systems provide excellent nationwide distribution, and for a firm to up its own sales and distribution network may require a very heavy investment. While the multi-stage distribution system may cause a profit squeeze to manufacturers and exporters and mean an added cost to the consumer, it also spreads risks and serves the purpose of financial hedging. While direct imports by department stores are increasing, they still account for only a small part of their total handling of foreign products and the potential exporter may have to deal with a trading firm or wholesaler rather than directly with department stores. Supermarket chains may constitute a suitable outlet as they are more interested in direct imports than other retailers. While direct entry into the Japanese market is very expensive, a liaison or sales branch office may be suitable for goods that require more attention than a trading company can offer. The function of the liaison office may be to gather market information, provide information for potential clients, and refer customers to distributors or trading companies. The sales or branch office takes orders and fills them. It may plan and carry out a full marketing programme. It is possible to make mistakes in the choice of distribution channels in Japan when a product is distributed to large stores rather than speciality stores or mass-selling channels are used for a non-mass product. When choosing distribution channels, product characteristics and market conditions should be taken into consideration.

Thus, the example of Japan provides an excelent illustration of the influence of the cultural environment.

\section{Political and legal forces}

When considering political and legal forces in foreign markets, it has to be realized that the policies of a government toward foreign firms, public versus private enterprise, and consumers all influence marketing. This is similarly the case with the political system, national laws, national pressure groups, regulatory bodies, and legislation and courts.

Saudi Arabia ranks as a rapidly growing import market between Europe and Japan. In Saudi Arabia, for example, although it adheres to the free-enterprise system, the royal family exercises control. Furthermore, there is a concentration of business interests in a small number of hands. There is also a blacklist of companies prohibited from selling their products and services in Saudi Arabia. The blacklist was initially produced in 1970 at the senate's subcommittee on multinational corporations. Companies were said to earn their blacklisting because of sympathy with Israel. As far as channels of communication are concerned, the Saudi government prohibits radio and TV stations from accepting advertising messages and all important publications are subject to close scrutiny by Saudi Government censors before being admitted. Motion-picture theatres are also banned in Saudi Arabia. The law prohibits the display or advertisement of symbols containing Christian connotations. Another point of importance to marketers is that women are not allowed to participate in the Saudi labour force.

As far as product policy in Saudi Arabia is concerned, an example of Saudi puritanism influencing products is that of a British brewery launching a non-alcoholic beer as the result of a ban on alcohol. Then, the fact that there are blacklisted companies requires companies to find out whether they are on the list and to decide whether or not to continue doing business with Israel. As far as pricing policies are concerned, government measures to counter inflationary pressures may have an effect, for example the 1973 subsidization of basic commodities and the urging of Saudi businessmen to keep prices of essential commodities within the reach of consumers. Concerning promotion policy, as a result of the prohibition on advertising in radio and TV, advertising expenditures have to be concentrated in newspapers, magazines, billboards, and direct mail. Foreign firms, in large trading areas have also tried to pursue promotional strategies such as maintaining showrooms and using Arabic posters for advertising. Advertisers also have to be careful, not to use women, nudity, and sex appeal in advertising messages as this is prohibited. As far as the sales force is concerned marketers must realize that they cannot use women because of the prohibition on their participation in the labour force. The major role played by prominent families in Saudi Arabia influences the channels of distribution as they control almost all channels of distribution, being known as channel captains. They may in fact be sought out by foreign companies who want them to join in joint venture deals. These channel captains have also 
been seen to be interested in foreign investment in joint projects because of the inflow of technology and managerial skills (Middle East Economic Digest, 1975:23).

There are many examples of government policies affecting marketers. This is also of significance in the communist countries where foreign trade organizations, state-owned government monopolies, buy from abroad if the purchase suits the national plan and if the goods required cannot be produced within the country. Japan provides an example because newly imported products are subject to rigid government analysis in view of one of the most stringent consumer protection codes in the world. There are also stringent Japanese standards for legal regulation of sales of goods.

Demographic factors such as population size, number of persons in families, age and regional distribution, birth and death rates, and distribution of families in various stages of the family life cycle all affect marketers. Only one of the demographic factors affecting marketers will be discussed here, that is rural versus urban distribution.

\section{Rural versus urban distribution}

Marketers tend to concentrate their efforts in the ready made and easily approachable urban markets. A reason for this is that urban markets are rich and involve less marketing costs and efforts. However, there is scope for rewarding sales in rural markets for a number of products. If a company ascertains that, in a foreign country, there is a large rural distribution of population, it should not find this a disincentive, but concentrate on a systematic study of the rural target market.

India is a country that has $80 \%$ of its population living in villages. Marketers wishing to involve themselves in the Indian rural market should be aware of the special characteristics of this market. The rural Indian has less purchasing power than the urban Indian. As a consumer his purchases are selective and cover only the bare necessities of life. Because his purchasing power is limited, substitutes are important to him. As the typical rural Indian is illiterate he is unaware of products and their uses. These two features tend to be typical of many rural markets particularly in the underdeveloped countries such as in, for example, Africa.

In India there is a large life-style gap among village people with numerous classes and divisions. This trait is also found in rural Africa with its different tribes. Geographically, rural villages tend to be scattered and this is particularly evident in India. Superstitions in rural India prevent the use of many products and families are ruled by elders who are not conducive to change and as the villager is traditional and conservative, new products are suspect and the barter system prevails. The villager spends much on marriage celebrations and death mournings, he is motivated in his spending by family pride and false honour.

Determining the characteristics of a target market such as rural India enables the marketer to make certain decisions concerning his product planning for such a market. Thus, for example, he would decide that the product should have needsatsifying qualities, that packing is unimportant, that the product should do something to maintain and improve the prestige of the family. Verma (1980:47 - 52) gives an example to illustrate the latter point. He explains how folding beds of iron pipes and sun-mica beds have succeeded as they increase their honour, bedding being given as part of dowry. As far as pricing policies are concerned, as the purchasing power of the rural Indian is low and consumers purchase substitutes, prices should be low and products may have to be sold initially at a loss, although a higher price could be charged on distinctive products. Promotion has the major function of information. Advertising is irrelevant because of the high illiteracy rate and the purchase of necessities. Selling should have the form of personal selling and product demonstrations, particularly at fairs and exhibitions. As previously noted in the case of countries in the early stages of development, in the case of rural markets there can also be advertisements via announcements by drum beatings, radio, and billboards. Physical distribution is difficult as transportation is poor, thus warehousing and standing facilities in feeder towns and places near villages can be developed, and business started in rural areas. Distribution can take place via street vendors who purchase goods from wholesalers, village shops, distributors and wholesalers. The number of distribution channels should be limited as the number of middlemen increase the price of the product as can be seen in the case of Japan.

\section{Conclusions}

The reader should realize that the aspects considered above are by no means exhaustive. There are other factors such as the geographic, technological, and commercial that influence marketing internationally. Space merely precludes their discussion. It is only after a firm thoroughly determines foreign market potentials and understands the foreign environment, that a marketing mix can be developed and adapted. This will only be the case if foreign marketing opportunities warrant the risk and expense of adapting the marketing mix. It may of course be possible that only minor changes are necessary or that there is no existing marketing mix because a new product has been developed for a particular country.

\section{References}

Ferrell, O.C. \& Pride, W.M. 1982. Fundamentals of marketing, Boston: Houghton Miflin Company.

Hasegawa, Y. 1978. Miti prepares pitfall guide for marketers, Ind. Marketing, vol.63, 62-64.

Middle East economic digest. 1975. Beer without Alcohol to be made for Saudis, p.23.

McCarthy,E.J. 1981. Basic marketing, Illinois, Homewood: Richard D Irwin Inc.

Verma, Y.S. 1980. 'Marketing in Rural India', Manage. Int. Rev., vol.20, (4), 47-52. 